\title{
Rapid and easy detection of the five most common founder mutations in BRCA1 and BRCA2 genes in the Polish population using CAPS and ACRS-PCR methods
}

\author{
Adam Dąbrowski ${ }^{1}$ Stanisław Ułaszewski² and Katarzyna Niedźwiecka2® \\ 'Laboratory of Molecular Diagnostics "Bio-Genetik" NZOZ, Wrocław, Poland; 2Institute of Genetics and Microbiology, University of Wroclaw, \\ Wrocław, Poland
}

In this publication, we present a fast method of diagnosing the most common polymorphisms of BRCA1 and BRCA2 genes in Poland - c.181T>G, pCys61Gly (also known as C61G), c.190T>C, p.Cys64Arg (aka C64R), c.4035delA, p.Glu1346Lysfs (aka 4153delA), c.3700_3704delGTAAA, p.Val1234GInfs (aka 3819del5), and c.5744C $>$ T, p.Thr1915Met (aka C5972T). Our procedure is based on the use of the cleaved amplified polymorphic sequences (CAPS) and artificially created restriction site (ACRS) PCR techniques. The precise selection of the appropriate primer sequences and restriction enzymes enabled specific cuts of DNA fragments. The final quantity and size of the obtained products depended on the presence or the absence of the mutations. The obtained results are unambiguous and do not have to be confirmed by sequencing. The methods of detection of the c.181T>G, C.190T>C, c.4035delA, c.3700 3704delGTAAA, and c.5744C $>$ T mutations in the $B R C A 1$ and $B R C A 2$ genes described by us do not require the sequencing process, which is more expensive, timeconsuming and associated with numerous errors. The technique developed by us enables the use of simple electrophoresis for accurate detection of the presence or absence of a specific mutation. Our procedure is fast, precise and unambiguous. It is very useful as the first step in the diagnostic of $B R C A 1 / 2$ constitutional mutations in Polish population in a small clinical laboratory.

Keywords: $B R C A 1$ mutations, $B R C A 2$ mutations, molecular diagnostics, CAPS, ACRS-PCR

Received: 08 August, 2018; revised: 08 September, 2018; accepted: 18 December, 2018; available on-line: 06 February, 2019

e-mail: katarzyna.niedzwiecka@uwr.edu.pl

Abbreviations: ACRS-PCR, artificially created restriction site-polymerase chain reaction; CAPS, cleaved amplified polymorphic sequences

\section{INTRODUCTION}

Breast cancer is one of the most common types of women's malignant tumors in almost all countries. It is also responsible for the majority of cancer-related deaths of women worldwide, and its incidence is increasing from year to year (Siegel et al., 2013; 2016). Genes associated with most of the hereditary cases of this disease are BRCA1 and BRCA2. Both are important repressive genes, which are crucial for maintaining the cell's genetic stability (Silver \& Livingston, 2012). Proteins encoded by these genes affect DNA repair and regulation of transcription in response to DNA damage. They are essential for maintaining chromosomal stability and interact with numerous proteins involved in apoptosis (Dubrovska et al., 2005). Mutations in BRCA1 and BRCA2 genes give the highest risk of developing breast cancer (up to $87 \%$ and $80 \%$, respectively) (Karami \& Mehdipour, 2013). Moreover, it has been reported that they are associated with a higher grade of breast cancer, increased metastasis and with a weaker prognosis compared to sporadic tumors and those caused by mutations in other genes (Musolino et al., 2007; Celebiler Cavusoglu et al., 2009). Mutation within BRCA1 and BRCA2 can occur almost anywhere. More than 2,000 different mutations have been described in their sequence (Karami \& Mehdipour, 2013). The frequency of the mutations occurrence varies among different populations. In the Polish population, the most common mutations in the BRCA1 gene include c.5266dupC (aka 5382insC), c.181T $>$ G, c.190T>C, c.4035delA, c.3700_3704delGTAAA (C61G, C64R, 4153delA, 3819del5), and in BRCA2 c.5744C>T (C5972T) (Grzybowska et al., 2002; Górski et al., 2004; Brozek et al., 2011; Karami \& Mehdipour, 2013, Wójcik et al., 2016). They are also common in other European countries (Karami \& Mehdipour, 2013). It is worth noting that these mutations may also cause increased progression of other cancers such as ovary, pancreas, colon, skin or prostate (Schorge et al., 2010; Mersch, 2016). For example, in the general population, the risk of developing ovarian cancer is around $1.6 \%$, while among $B R C A 1$ and $B R C A 2$ gene mutation carriers it increases to $60 \%$ and 27\%, respectively (Antoniou et al., 2005; Hyman et al., 2013). It should also be noted that $30-50 \%$ of women with $B R C A 1 / B R C A 2$ mutations do not have a family history of breast or ovarian cancer (Brozek et al., 2012).

Considering the above information, it cannot be denied that the rapid and effective detection of the mentioned mutations increases the chance of successful diagnosis and therapy of possible cancer diseases. In this study, CAPS (cleaved amplified polymorphic sequences) and ACRS-PCR (artificially created restriction site PCR) methods were used to perform fast and accurate detection of five of the most common and important polymorphisms of BRCA1 and BRCA2 genes in the Polish population.

\section{MATERIALS AND METHODS}

All restriction enzymes and products necessary for the amplification process were purchased from Thermo Fisher Scientific (USA) and EURx (Poland). GeneMATRIX Quick Blood DNA Purification and GeneMATRIX Swab-Extract DNA Purification Kits were purchased from EURx (Poland). 
Table 1. The sequences of the mutated fragments of BRCA1 and BRCA2 genes, examined in this paper

\begin{tabular}{ll}
\hline Mutation & Position of the analyzed mutations in the BRCA1 and BRCA2 genes \\
\hline c.190T>C (C64R) & GAAAGGCCTTCACAGTGTCCTTTA[T/C]GTAAGAATGATATAACCAAAAGGTA \\
\hline c.181T>G (C61G) & CAACCAGAAGAAAGGGCCTTCACAG[T/G]GTCCTTTATGTAAGAATGATATAAC \\
\hline C.4035delA (4153delA) & ACAAGGAATTGGTTTCAGATGATGA[A/-]GAAAGAGGAACGGGCTTGGAAGAAA \\
\hline c.3700_3704delGTAAA (3819del5) & CTTCCAACACTTGTTATTTGGTAAA[GTAAA/-]CAATATACCTTCTCAGTCTACTAGG \\
\hline C.5744C $>$ T (C5972T) & CTCTCTAGATAATGATGAATGTAGCA[C/T]GCATTCACATAAGGTTTTGCTGAC \\
\hline
\end{tabular}

Isolation of genomic DNA from the clinical samples. The research material in the form of blood samples and buccal swabs came from patients of the Molecular Diagnostics Laboratory 'Bio-Genetik' in Wroclaw, Poland. The isolation of genomic DNA was carried out using DNA Purification Kits. The concentration of DNA was determined using a spectrophotometer (Pharmacia Biotech GeneQuant II).

Detection of the mutations. Positive and negative patient samples were previously assessed by sequencing. Sanger sequencing chromatograms were compared to the reference sequences of the NM_007294.3 (BRCA1) and NM_000059.3 (BRCA2) genes, exactly at the mutation loci: rs28897672 for c.181T>G, rs80357064 for c. $190 \mathrm{~T}>\mathrm{C}$, rs 80357711 for c. $4035 \mathrm{delA}$, rs80357609 for c.3700_3704delGTAAA and rs4987117 for c.5744C $>$ T. Carriers of BRCA1 and BRCA2 gene mutations (Table 1) were identified using CAPS and ACRS-PCR methods (Hosseini et al., 2006). PCR amplifications were performed using Perpetual OptiTaq DNA Polymerase (EURx) in a T100 Thermal cycler (Bio-Rad). The final volume of $50 \mu \mathrm{l}$ of each sample contained $0.2 \mu \mathrm{M}$ of each primer, $0.2 \mathrm{mM}$ of each dNTP, and 50-100 ng of the genomic DNA. The thermal cycling conditions were as follows: $94^{\circ} \mathrm{C}$ for $10 \mathrm{~min}$, followed by 40 cycles at $94^{\circ} \mathrm{C}$ for $30 \mathrm{~s}, 60^{\circ} \mathrm{C}$ for $30 \mathrm{~s}$ and $72^{\circ} \mathrm{C}$ for $30 \mathrm{~s}$. Then, the final extension at $72^{\circ} \mathrm{C}$ took $5 \mathrm{~min}$. Amplification of the selected DNA fragments (within the areas of exons) was performed using carefully selected primers (designed based on the sequence of genes deposited in the GenBank database) which are presented in Table 2.

Subsequently, the PCR products $(15 \mu \mathrm{l})$ were digested with the appropriate restriction enzymes (Table 3) and at appropriate temperatures for 3-16 hrs. The resulting DNA fragments were separated in $0.5 x$ TBE buffer using $2 \%$ low EEO agarose (EURx) with SimplySafe ${ }^{\mathrm{TM}}$ (EURx) and visualized under ultraviolet light.
c.181T $>$ G, c.190T $>C$ and c.5744C $>$ T. The c. $181 \mathrm{~T}>\mathrm{G}$, c.190T $>\mathrm{C}$ and c.5744C $>\mathrm{T}$ mutations are associated with the substitution of nitrogen bases (Table 1). In all three cases, the typical CAPS method was used for diagnostic purposes. First, DNA fragments were amplified including additional nucleotides flanking the analyzed point mutations (Table 2). Then, the Sna$B I, T s c A I$ and $S p h I$ enzymes were used, to restrict the mutated or wild fragment of the BRCA1 and BRCA2 genes (Table 3). For monitoring purposes, the AanI and Hind III enzymes, which cut the amplified fragments regardless of the presence of the mutations, were used (Table 3).

c.4035delA and c.3700_3704delGTAAA. The other mutations in the $B R \bar{C} A 1$ gene, c.4035delA and c.3700_3704delGTAAA, are the result of the deletion of one or five nucleotides in the gene sequence ( $\mathrm{Ta}$ ble 1). The detection of these mutations requires the simultaneous use of the CAPS method and the ACRSPCR technique. Due to the lack of restriction enzymes recognizing the sequences in which these mutations occur, appropriate sites were created for amplification by designing modified oligonucleotides (Table 2). Manipulation in the primer sequence allowed replication of the desired BRCA1 gene fragments with a change in a single nucleotide. Thanks to that, sequences including possible mutations are recognized by the enzymes AcuI and HpaI for c.4035delA and c.3700_3704delGTAAA, respectively (Table 3). AcuI cuts the wild-type form of the gene, and HpaI recognizes the site of the c.3700_3704delGTAAA mutation. Simultaneously with HpaI, the enzyme SspI was used to monitor the reaction success (Table 3).

\section{RESULTS}

The use of the appropriate primers and restriction enzymes enabled specific cuts of DNA fragments. The final quantity and size of the obtained products depend-

Table 2. Oligonucleotides used for PCR amplification

\begin{tabular}{ll}
\hline Primer & Sequence 5'-3' \\
\hline C64R_For & TCAACCAGAAGAAAGGGCT product size \\
\hline C64R_Rev & AGGCAGATGTCCCATAAAACTT \\
\hline C61G_For & TGGCTCTTAAGGGCAGTGGTG \\
\hline C61G_Rev & GTGGTGCTTCCAACCTAGC \\
\hline 4153delA_For & GACAAGGAATTGGTTCAGATGCTG \\
\hline 4153delA_Rev & GTGCTCCCCAAAAGCATAAAC \\
\hline 3819del5_For & CCAACACTTGTATTGGTAA \\
\hline 3819 del5_Rev & GAAGAAACAAGCTAGCAGAACA \\
\hline C5972T_For & AGGTTGTTACGAGGCATTGG \\
\hline C5972T_Rev & GCAGATGAGACTGACTATGAAGC \\
\hline
\end{tabular}


Table 3. Cleavage site of restriction enzymes used in this study and size of the expected products after restriction in the case of nonmutated homozygote and mutated heterozygote

\begin{tabular}{|c|c|c|c|}
\hline Mutation & Fragment of the gene after amplification & $\begin{array}{l}\text { Wild } \\
\text { type }\end{array}$ & $\begin{array}{c}\text { Mutated } \\
\text { heterozygote }\end{array}$ \\
\hline c.190T>C (C64R) & 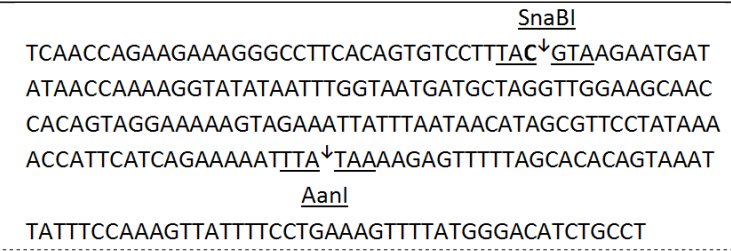 & $\begin{array}{l}165 \mathrm{bp} \\
72 \mathrm{bp}\end{array}$ & $\begin{array}{l}165 \mathrm{bp} \\
129 \mathrm{bp} \\
36 \mathrm{~b} \\
72 \mathrm{bp}\end{array}$ \\
\hline c. $181 \mathrm{~T}>\mathrm{G}(\mathrm{C} 61 \mathrm{G})$ & $\begin{array}{l}\underline{\underline{\text { IscAl }}} \\
\text { TGGCTCTTAAGGGCAGTGGT }{ }^{\downarrow} \text { GAGATTATCTTTTCATGGCTATTTGCCT } \\
\text { TTTGAGTATTCTTTCTACAAAAGGAAGTAAATTAAATTGTTCTTCTTTCT } \\
\text { TTATAATTTATAGATTTGCATGCTGAAACTTCTCAACCAGAAGAAAGG } \\
\text { GCCTTCACAGTGTC } \frac{{ }^{\downarrow} \text { CTTTATGTAAGAATGATATAACCAAAAGGTATAT }}{\text { IscAI }} \\
\text { AATTTGGTAATGATGCTAGGTTGGAAGCAACCAC }\end{array}$ & $\begin{array}{l}142 \mathrm{bp} \\
68 \mathrm{bp} \\
20 \mathrm{bp}\end{array}$ & $\begin{array}{l}210 \mathrm{bp} \\
142 \mathrm{bp} \\
68 \mathrm{bp} \\
20 \mathrm{bp}\end{array}$ \\
\hline c.4035delA (4153delA) & $\begin{array}{l}\frac{\text { Acul }}{\text { GACAAGGAATTGGTTTCAGATGCTGAAGAAAGAGGAACGGGCTT }}{ }^{\downarrow} \text { GG } \\
\text { AAGAAAATAATCAAGAAGAGCAAAGCATGGATTCAAACTTAGGTATTG } \\
\text { GAACCAGGTTTTGTGTTTGCCCCAGTCTATTTATAGAAGTGAGCTAAA } \\
\text { TGTTTATGCTTTTGGGGAGCAC }\end{array}$ & $\begin{array}{l}121 \mathrm{bp} \\
44 \mathrm{bp}\end{array}$ & $\begin{array}{l}164 \mathrm{bp} \\
121 \mathrm{bp} \\
44 \mathrm{bp}\end{array}$ \\
\hline $\begin{array}{l}\text { c.3700_3704delGTAAA } \\
\text { (3819del5) }\end{array}$ & 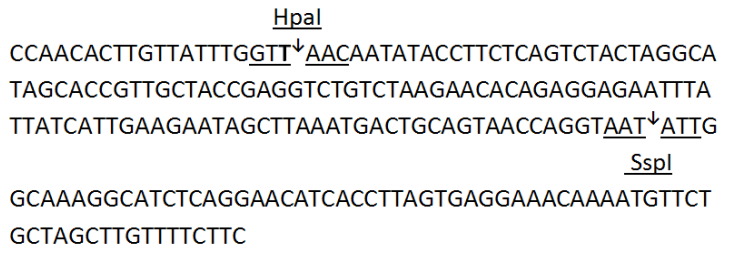 & $\begin{array}{l}147 \mathrm{bp} \\
69 \mathrm{bp}\end{array}$ & $\begin{array}{l}147 \mathrm{bp} \\
122 \mathrm{bp} \\
69 \mathrm{bp} \\
20 \mathrm{bp}\end{array}$ \\
\hline c.5744C>T (C5972T) & 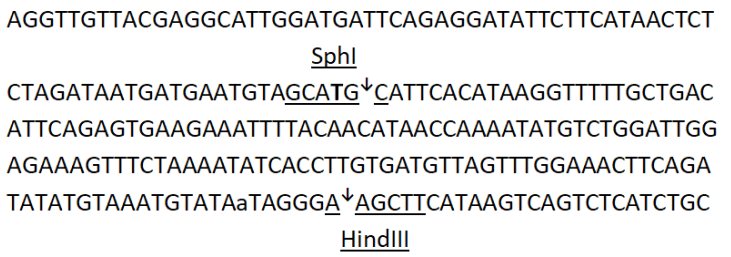 & $\begin{array}{l}218 b p \\
25 b p\end{array}$ & $\begin{array}{l}218 \mathrm{bp} \\
145 \mathrm{bp} \\
73 \mathrm{bp} \\
25 \mathrm{bp}\end{array}$ \\
\hline
\end{tabular}

ed on the presence or absence of the specific mutations (Table 3). On this basis, changes in specific sequences could be unambiguously confirmed or excluded.

The presence of the c.190T $>$ C, c.3700_370-4delGTAAA, and c.5744C>T (heterozygote) mutations is associated with the substitution of the thymine base by cytosine $[\mathrm{T} / \mathrm{C}]$, deletion of five nitrogen bases [GTAAA/-] and transition of cytosine to thymine $[\mathrm{C} / \mathrm{T}]$, respectively (Table 1$)$. After amplification using appropriate primers, 237 bp (c.190T $>$ C), 216/211 bp (c.3700_3704delGTAAA) and 243 bp (c.5744C>T) products were obtained. SnaBI, HpaI and SphI restric-

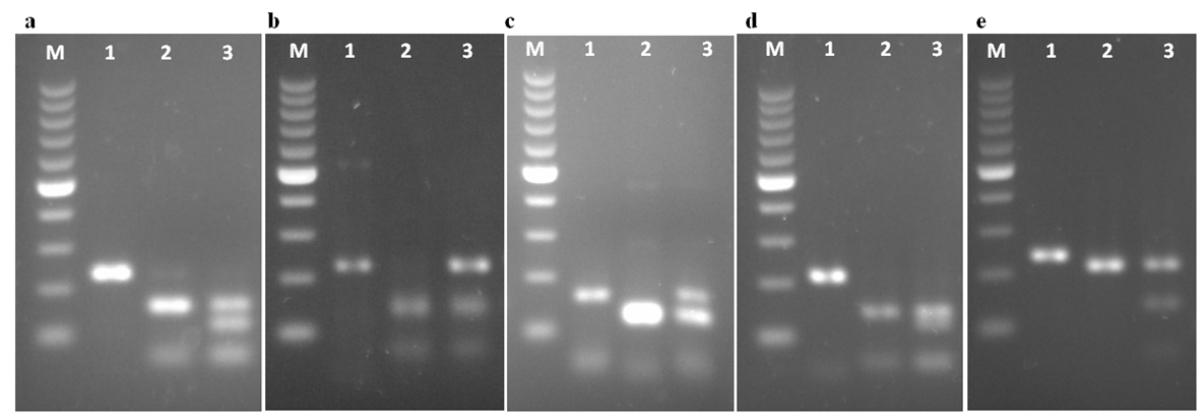

Figure 1. PCR products of the BRCA1 and BRCA2 genes fragments including the C.190T>C (a), c.181T>G (b), c.4035delA (c), c.3700 3704delGTAAA (d) and c.5744C $>$ T (e) mutations.

$\mathrm{M}$, mass ladder (100-1000 bp); 1, undigested PCR product; 2, wild-type gene (unmutated homozygote); 3, presence of a mutation (mutated heterozygote). 
tion enzymes used to detect these mutations recognized mutated DNA fragments. Therefore, at the same time, the additional enzymes were used to monitor the reaction success. Ultimately, the presence of the c.190T $>$ C, c.3700_3704delGTAAA or c.5744C $>$ T (heterozygote) mutations determined the creation of four products of a precisely defined size, while the absence of a mutation (non-mutated homozygote) determined the creation of two specific products in all three cases (Table 3, Fig. 1a, $\mathrm{d}, \mathrm{e})$. The remaining mutations in the BRCA1 gene, c. $181 \mathrm{~T}>\mathrm{G}$ and c.4035delA, are the result of thymine transversion into guanine and adenine deletion, respectively (Table 1). Amplification using carefully selected primers included areas flanking the possible mutations

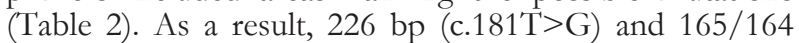
bp (c.4035delA) products were obtained. The restriction enzymes TscAI for c.181T $>\mathrm{G}$ and AcuI for c.4035delA recognized the unmutated gene sequences, and thus they did not require an additional enzyme to monitor the success of the reaction (Table 3 ). Tsc AI recognizes two cutting locations. Consequently, the presence of the c. $4035 \mathrm{delA}$ mutation was characterized by three products of a specific size and the lack of the mutation was associated with the visualization of two distinctive products after electrophoresis (Table 3, Fig. 1c). The c.181T $>$ G mutation gave four products of a precisely defined size. However, when dealing with the wild-type gene we obtained three bands (Table 3, Fig. 1b).

\section{DISCUSSION}

The methods we present allow confirmation or exclusion of the presence of the c.181T $>$ G, c.190T $>$ C, c.4035delA, c.3700_3704delGTAAA, and c.5744C $>$ T mutations in the BRCA1 and BRCA2 genes. As a matter of fact, it is possible to obtain the result just a few hours after receiving the sample for testing, regardless of the number of patients examined. All procedures are based on the research techniques that can be performed in any laboratory equipped with basic molecular biology equipment. The final step, based on plain horizontal agarose gel electrophoresis, provides unambiguous results, which do not have to be further confirmed. In order to monitor the success of the reaction, simultaneously, additional enzymes operating under the same conditions and using the same buffer are used. We used this technique when dealing with direct detection of the mutated form of the sequences - c.5744C $>$ T c.190T $>C$ and c.3700_3704delGTAAA. The additional enzyme cuts the PCR product regardless of the presence of the mutation. This makes it possible to eliminate cases in which errors could occur due to any inhibition of the reaction at the PCR product digestion stage. A frequent problem is the inhibition of digestion caused, for example, by contamination or inactivation of the chemical reagents. Then, the lack of the digestion can be misinterpreted as "no mutation". Therefore, the control in the form of an additional restriction enzyme is an important factor for the results reliability. There is no such threat for an enzyme that digests a wild-type version of the sequence as in the case of detection of c.4035delA and c.181T $>G$ mutations. This is connected with the fact that the majority of mutations in the BRCA1 and BRCA2 genes in homozygous form are lethal during embryonic development. Therefore, this form does not appear in the population (Liu et al., 1996). Thus, in the vast majority of cases mutations in the BRCA1 and BRCA2 genes occur in heterozygous form (Zheng et al., 2000; Smith et al., 2013;
Domchek et al., 2014). It should also be mentioned that in a typical agarose gel, bands of about 20-50 bp are very poorly visible. However, other larger products are sufficient for effective diagnostics.

In order to detect mutations in the BRCA1 and $B R C A 2$ genes the CAPS and ACRS-PCR techniques were used previously. For example, in the case of the c.5744C>T mutation Górski and others (Górski et al., 2005) used the ACRS-PCR method using only a single enzyme. As a consequence, the mutated PCR product was only slightly shortened in comparison to the wildtype version. A minor shortening of the amplification product is very difficult to detect using ordinary electrophoresis; therefore, all cases had to be confirmed by sequencing. Sequence analysis of the gene fragments is a widely used method to detect the mutations in $B R C A 1$ and BRCA2 (Nunziato et al., 2017; Suryavanshi et al., 2017). However, it should be remembered that due to the fact that mutations mostly occur only in one gene allele (Zheng et al., 2000; Smith et al., 2013; Domchek et al., 2014), the sequencing process often gives results that are difficult to interpret. In addition, sequencing detects new, individual single nucleotide polymorphisms, the presence of which has not been linked to an inheritable susceptibility to cancer (e.g. non-pathogenic variation). This may lead to a hasty interpretation by clinicians.

The methods of detection of the c.181T $>\mathrm{G}$, c.190T $>$ C, c.4035delA, c.3700_3704delGTAAA, and c. $5744 C>T$ mutations in the $B R \bar{C} A 1$ and $B R C A 2$ genes described by us are the results of a careful refinement of the sequence of primers used for the amplification reaction accompanied by the precise selection of specific restriction enzymes. These procedures made it possible to abandon the expensive and time-consuming sequencing process. The methods presented in this publication are fast, accurate and unambiguous. They allow cutting the DNA fragments into products of a precisely defined size, clearly indicating the presence or the absence of the tested mutations. A quick and accurate method of detecting mutations in the BRCA1 and BRCA2 genes is extremely important. It enables a rapid initiation of the treatment, which increases the probability of the successful therapy. It is also worth noting that many physicians make the decision about the type of used pharmacological agents and/or mastectomy or ovariectomy dependently on the presence or absence of the mutations in these genes. The procedures described by us in a combination with the detection of the c.5266dupC (5382insC) mutation using the DdeI endonuclease (Kirchhoff et al., 2009) allow obtaining a diagnostic set for six mutations in the $B R C A 1$ and BRCA2 genes recommended for the Polish population. The average cost of all reagents for the analysis of the six mutations for one patient does not exceed 25 Euros and, usually, it is possible to get the result on the next day after receiving the sample for testing. Using the CAPS and ACRS-PCR techniques, the panel of BRCA1/2 founder mutations can be optionally extended to the other polymorphisms. For example, the mutation c.5251C > T (p.Arg1751Ter) will be routinely performed in our laboratory as a new founder mutation (Kowalik et al., 2018). This variation has been detected in $15 \%$ of all BRCA1 mutations in a screening of about 3000 women or their close relatives with breast/reproductive organs tumors. In this case, it is easy to exploit the ACRS-PCR technique with TscAI restriction enzyme to confirm transposition of the arginine codon CGA to the stop codon TGA. 


\section{Disclosure Statement}

The authors declared no conflict of interest.

\section{Ethics approval and consent to participate}

All participants gave informed consent prior to enrolling in the research.

\section{Acknowledgements}

This work was supported by the Ministry of Science and Higher Education (Poland) within "Statutory Research 2018/S/IGM".

\section{REFERENCES}

Antoniou AC, Pharoah PDP, Narod S, Risch HA, Eyfjord JE, Hopper JL, Olsson H, Johannsson O, Borg A, Pasini B, Radice P, Hopper JL, Olsson H, Johannsson O, Manoukian S, Eccles DM, Tang N, Olah E, Warner E, Lubinski J, Gronwald J, Gorski B, Tulinius H, Thorlacius S, Eerola H, Nevanlinna H, Syrjäkoski K, Kallioniemi O-P, Thompson D, Evans C, Peto J, Lalloo F, Evans DG, Easton DF (2005) Breast and ovarian cancer risks to carriers of the $B R C A 1$ 5382insC and 185delAG and BRCA2 6174delT mutations: a combined analysis of 22 population based studies. I Med Genet 42: 602-603. https://doi.org/10.1136/jmg.2004.024133

Brozek I, Cybulska C, Ratajska M, Piatkowska M, Kluska A, Balabas A, Dabrowska M, Nowakowska D, Niwinska A, Pamula-Pilat J, Tecza K, Pekala W, Rembowska J, Nowicka K, Mosor M, Januszkiewicz-ewandowska D, Rachtan J, Grzybowska E, Nowak J, Steffen J, Limon J (2011) Prevalence of the most frequent BRCA1 mutations in Polish population. I Appl Genet 52: 325-330. https://doi. org/10.1007/s13353-011-0040-6

Brozek I, Ratajska M, Piatkowska M, Kluska A, Balabas A, Dabrowska M, Nowakowska D, Niwinska A, Rachtan J, Steffen J, Limon J (2012) Limited significance of family history for presence of BRCA1 gene mutation in Polish breast and ovarian cancer cases. Fam Cancer 11: 351-354. https://doi.org/10.1007/s10689-012-9519-5

Celebiler Cavusoglu A, Kilic Y, Saydam S, Canda T, Baskan Z, Sevinc AI, Sakizli M (2009) Predicting invasive phenotype with CDH1, $\mathrm{CDH} 13, \mathrm{CD} 44$, and TIMP3 gene expression in primary breast cancer. Cancer Sci 100: 2341-2345. https://doi.org/10.1111/j.13497006.2009.01333.x

Domchek SM, Tang J, Stopfer J, Lilli DR, Hamel N, Tischkowitz M, Monteiro ANA, Messick TE, Powers J, Yonker A, Couch FJ, Goldgar DE, Davidson HR, Nathanson KL, Foulkes WD, Greenberg RA (2014) Biallelic deleterious BRCA1 mutations in a woman with early-onset ovarian cancer. Cancer Discov 3: 399-405. https://doi. org/10.1158/2159-8290.CD-12-0421

Dubrovska A, Kanamoto T, Lomnytska M, Heldin C-H, Volodko N, Souchelnytskyi S (2005) TGFbeta1/Smad3 counteracts BRCA1-dependent repair of DNA damage. Oncogene 24: 2289-2297. https:// doi.org/10.1038/sj.onc.1208443

Górski B, Jakubowska A, Huzarski T, Byrski T, Gronwald J, Grzybowska E, Mackiewicz H, Niepsuj S, Góźdź S, Zaremba L, Posmyk M, Płużańska M, Kilar E, Czudowska D, Waśko B, Miturski R, Kowalczyk JR, Urbański K, Szwiec M, Koc J, Dębniak B, Rozmiarek A, Dębniak T, Cybulski C, Kowalska E, Tołoczko-Grabarek A, Zajączek S, Menkiszak J, Mędrek K, Masojć B, Mierzejewski M, Narod AS, Lubiński J (2004) A high proportion of founder BRCA1 mutations in Polish breast cancer families. Int J Cancer 110: 683-686. https://doi.org/10.1002/ijc.20162

Górski B, Narod SA, Lubiński J (2005) A common missense variant in $B R C A 2$ predisposes to early onset breast cancer. Breast Cancer Res 7: R1023-7. https://doi.org/10.1186/bcr1338

Grzybowska E, Siemińska M, Zientek H, Kalinowska E, Michalska J, Utracka-hutka B, Rogozińska-Szczepka J, Kaźmierczak-Maciejewska M (2002) Germline mutations in the BRCA1 gene predisposing to breast and ovarian cancers in Upper Silesia population. Acta Biochem Pol 49: 351-356
Hosseini SY, Sabahi F, Amini-Bavil-Olyaee S, Alavian S-M, Merat S (2006) A novel accurate ACRS-PCR method with a digestion internal control for identification of wild type and YMDD mutants of hepatitis B virus strains. J Virol Methods 137: 298-303. https://doi. org/10.1016/j.jviromet.2006.07.008

Hyman DM, Zhou Q, Iasonos A, Grisham RN, Arnold AG, Phillips MF, Bhatia J, Levine DA, Aghajanian C, Offit K, Barakat RR, Spriggs DR, Kauff ND (2013) Improved survival for BRCA2-associated serous ovarian cancer compared with both BRCA-negative and BRCA1-associated serous ovarian cancer. Cancer 118: $3703-$ 3709. https://doi.org/10.1002/cncr.26655

Karami F, Mehdipour P (2013) A Comprehensive Focus on Global Spectrum of $B R C A 1$ and $B R C A 2$ Mutations in Breast Cancer. Biomed Res Int 2013: 1-21. https://doi.org/10.1155/2013/928562

Kirchhoff T, Kauff ND, Mitra N, Nafa K, Huang H, Palmer C, Gulati T, Wadsworth E, Donat S, Robson ME, Ellis NA, Offit K (2004) $B R C A$ Mutations and Risk of Prostate Cancer in Ashkenazi Jews. Clin Cancer Res 10: 2918-2921. https://doi.org/10.1158/1078-0432. CCR-03-0604

Kowalik A, Sioøek M, Kopczyński J, Krawiec K, Kalisz J, Zięba S, Kozak-Klonowska B, Wypiórkiewicz E, Furmańczyk J, NowakOzimek E, Chłopek M, Macek P, Smok-Kalwat J, Góźdź S (2018) $B R C A 1$ founder mutations and beyond in the Polish population: A single-institution $B R C A 1 / 2$ next-generation sequencing study. PLoS ONE 13: e0201086. https://doi.org/10.1371/journal.pone.0201086

Liu C-Y, Flesken-Nikitin A, Li S, Zeng Y, Lee W-H (1996) Inactivation of the mouse Brcal gene leads to failure in the morphogenesis of the egg cylinder in early postimplantation development. Genes Dev 10: 1835-1843. https://doi.org/10.1101/gad.10.14.1835

Mersch J (2016) Cancers Associated with BRCA1 and BRCA2 Mutations other than Breast and Ovarian. Cancer 121: 269-275. https:// doi.org/10.1002/cncr.29041

Musolino A, Bella MA, Bortesi B, Michiara M, Naldi N, Zanelli P, Capelletti M, Pezzuolo D, Camisa R, Savi M, Neri TM, Ardizzoni A (2007) BRCA mutations, molecular markers, and clinical variables in early-onset breast cancer: A population-based study. Breast 16: 280-292. https://doi.org/10.1016/j.breast.2006.12.003

Nunziato M, Starnone F, Lombardo B, Pensabene M, Condello C, Verdesca F, Carlomagno C, De Placido S, Pastore L, Salvatore F, D'Argenio V (2017) Fast Detection of a BRCA2 Large Genomic Duplication by Next Generation Sequencing as a Single Procedure : A Case Report. Int J Mol Sci 18: 1-9. https://doi.org/10.3390/ ijms18112487

Schorge JO, Modesitt SC, Coleman RL, Cohn DE, Kauff ND, Duska LR, Herzog TJ (2010) SGO White Paper on Ovarian Cancer: Etiology, Screening and Surveillance. Gynecol Oncol Elsevier Inc. 119: 7-17. https:// doi.org/10.1016/j.ygyno.2010.06.003

Siegel R, Naishadham D, Jemal A (2013) Cancer Statistics, 2013. CA Cancer I Clin 63: 11-30. https://doi.org/10.3322/caac.21166

Siegel RL, Miller KD, Jemal A (2016) Cancer Statistics , 2016. CA Cancer J Clin 66: 7-30. https://doi.org/10.3322/caac.21332

Silver DP, Livingston DM (2012) Mechanisms of BRCA1 Tumor Suppression. Cancer Discov 2: 679-684. https://doi.org/10.1158/2159_ 8290.CD-12-0221

Smith KR, Hanson HA, Hollingshaus MS (2013) BRCA1 and BRCA2 mutations and female fertility. Curr Opin Obstet Gynecol 25: 207-213. https://doi.org/10.1097/GCO.0b013e32835f1731

Suryavanshi M, Kumar D, Kumar Panigrahi M, Chowdhary M, Mehta A (2017) Detection of false positive mutations in $B R C A$ gene by next generation sequencing. Fam Cancer 16: 311-317. https://doi. org/10.1007/s10689-016-9955-8

Wójcik P, Jasiowka M, Strycharz E, Sobol M, Hodorowicz-Zaniewska D, Skotnicki P, Byrski T, Blecharz P, Marczyk E, Cedrych I, Jakubowicz J, Lubiński J, Sopik V, Narod S, Pierzchalski P (2016) Recurrent mutations of BRCA1, BRCA2 and PALB2 in the population of breast and ovarian cancer patients in Southern Poland. Hered Cancer Clin Pract 14: 5. https://doi.org/10.1186/ s13053-016-0046-5

Zheng L, Li S, Boyer TG, Lee W-H (2000) Lessons learned from $B R C A 1$ and BRCA2. Oncogene 19: 6159-6175. https://doi. org/10.1038/sj.onc.1203968 